\title{
The Relationship between Glucose Transport and the Production of Succinoglucan Exopolysaccharide by Agrobacterium radiobacter
}

\author{
By ALEX CORNISH, JACQUELINE A. GREENWOOD AND \\ COLIN W. JONES* \\ Department of Biochemistry, University of Leicester, Leicester LEI 7RH, UK
}

(Received 15 June 1988; revised 8 August 1988)

Agrobacterium radiobacter NCIB 11883 was grown in ammonia-limited continuous culture at low dilution rate with glucose as the carbon source. Under these conditions the organism produced an extracellular succinoglucan polysaccharide and transported glucose using the same periplasmic glucose-binding proteins (GBP1 and GBP2) as during glucose-limited growth. Transition from glucose- to ammonia-limited growth was accompanied by a very rapid decrease in glucose uptake capacity, whereas the glucose-binding proteins were diluted out much more slowly $\left(t_{1 / 2}\right.$ approximately $1 \mathrm{~h}$ and $14 \mathrm{~h}$ respectively). Although the rate of glucose uptake and the concentrations of GBP1 and GBP2 were much lower during ammonia limitation, the activities of enzymes involved in the early stages of glucose metabolism and in the production of succinoglucan precursors were essentially unchanged. Glucose transport was also investigated in two new strains of $\boldsymbol{A}$. radiobacter which had been isolated following prolonged growth under glucose limitation. Glucose uptake by strain AR18 was significantly less repressed during ammonia limitation compared with either the original parent strain or strain AR9, and this was reflected both in its relatively high concentration of GBP1 and in its significantly higher rate of succinoglucan synthesis. Flux control analysis using 6-chloro-6-deoxy-D-glucose as an inhibitor of glucose transport showed that the latter was a major kinetic control point for succinoglucan production. It is concluded that glucose uptake by $A$. radiobacter, particularly via the GBP1dependent system, is only moderately repressed during ammonia-limited growth and that the organism avoids the potentially deleterious effects of accumulating excess glucose by converting the surplus into succinoglucan.

\section{INTRODUCTION}

Agrobacterium radiobacter NCIB 11883 is a recently isolated aerobic bacterium that produces a succinoglucan exopolysaccharide during growth in continuous culture under carbon-excess, oxygen-sufficient conditions (Linton et al., 1987a,b). The polymer contains glucose, galactose, succinate, pyruvate and acetate in the molar ratio $7: 1: 1: 1: 0 \cdot 1$ and is produced at maximal rate during growth under ammonia limitation at a dilution rate of $0.045 \mathrm{~h}^{-1}$ (Linton et al., 1987a).

Many exopolysaccharide-producing bacteria synthesize polysaccharides at progressively lower rates during prolonged growth in continuous culture or following repeated subculture. In some instances the biochemical basis for this deterioration has not yet been established (Sutherland, 1982), but in others it is clearly due to the emergence of new strains that have completely lost the capacity to produce exopolysaccharide. Such non-producing strains have been used to map genes involved in the biosynthesis of exopolysaccharides such as alginate (Darzins et al., 1985 b) and xanthan (Thorne et al., 1987) and in some cases it has proved possible to demonstrate that the inability to produce polymer is due to the loss of a specific enzyme in the

\footnotetext{
Abbreviations: FCCP, carbonyl cyanide p-trifluoromethoxyphenylhydrazone; FPLC, fast protein liquid
} chromatography; GBP, glucose-binding protein. 
biosynthetic pathway (Darzins et al., 1985a). Unfortunately, however, these genetic studies have failed to identify the factors that control the rate of exopolysaccharide synthesis in the original producing strains. Indeed, it is possible that the enzymes involved specifically in exopolysaccharide synthesis are of minor importance in controlling the overall rate at which the carbon substrate is converted into polymer (i.e. they possess low flux control coefficients; see Kell \& Westerhoff, $1986 a, b$ ).

In the accompanying paper we reported that $A$. radiobacter produces two periplasmic, glucose-binding proteins during glucose-limited growth, both of which appear to be components of discrete glucose transport systems (Cornish et al., 1988). The aim of the present work was to establish whether the same glucose transport systems are active during ammonia-limited growth and to determine the extent to which the rate of succinoglucan production is controlled by the activities of enzymes involved in the uptake and initial metabolism of glucose.

\section{METHODS}

Organism and growth conditions. The parent strain of $A$. radiobacter NCIB 11883 used in this word was obtained from Dr J. D. Linton, Shell Research Ltd, Sittingbourne, Kent, UK. A. radiobacter strains AR9 and AR18 were subsequently obtained by growing the parent organism under prolonged glucose limitation (see accompanying paper: Cornish et al., 1989), and were stored in $20 \%(\mathrm{v} / \mathrm{v})$ glycerol at $-70^{\circ} \mathrm{C}$.

Glucose-limited growth was carried out as described previously (Cornish et al., 1988). In order to achieve ammonia-limited growth (steady-state biomass density $=1.1 \mathrm{gl}^{-1}$ ) the input concentration of ammonium sulphate was reduced to $0.5 \mathrm{~g}^{-1}$ and the glucose concentration was increased to $16 \mathrm{~g} \mathrm{I}^{-1}$ unless stated otherwise. For $\mathrm{K}^{+}$-limited growth (steady-state biomass density $=1.1 \mathrm{~g}$ dry wt $\mathrm{l}^{-1}$ ) glucose was added to the culture at an input concentration of $15 \mathrm{~g} \mathrm{l}^{-1}, \mathrm{KH}_{2} \mathrm{PO}_{4}$ was replaced by $\mathrm{Na}_{2} \mathrm{HPO}_{4}$ plus $0.2 \mathrm{mM}-\mathrm{KCl}$ and the pH of the culture was maintained at 7.0 using $2 \mathrm{M}-\mathrm{NaOH}$ instead of $\mathrm{KOH}$.

Preparation of cell suspensions. Cell suspensions were prepared from glucose-limited cultures using $20 \mathrm{~mm}$ HEPES/KOH buffer, pH 7.0 as described previously (Cornish et al., 1987). Samples from ammonia- and $\mathrm{K}^{+-}$ limited cultures were diluted by an appropriate factor using $20 \mathrm{~mm}$-HEPES, pH 7.0, before the initial centrifugation to facilitate separation of the cells from the highy viscous succinoglucan exopolysaccharide present in the supernatant. Succinoglucan was precipitated using propan-2-ol (4 vols propan-2-ol:1 vol. supernatant), collected using a glass rod, and then dried to constant weight at $100^{\circ} \mathrm{C}$.

Measurement of succinoglucan production by batch cultures. $A$. radiobacter was grown at $30^{\circ} \mathrm{C}$ in baffled flasks containing $130 \mathrm{ml}$ minimal medium (Linton et al., 1987a) supplemented with ammonium sulphate $\left(0.22 \mathrm{~g}^{-1}\right)$ and either glucose or sucrose $\left(8 \mathrm{~g}^{-1}\right)$. Following inoculation, cells grew exponentially until the ammonia was exhausted (cell density $=0.5 \mathrm{~g} \mathrm{dry} \mathrm{wt}^{-1}$ ) and thereafter produced succinoglucan. The culture was harvested $24 \mathrm{~h}$ after inoculation and the concentration of succinoglucan was measured as described above. The $\mathrm{pH}$ was maintained at $6.8 \pm 0.2$ by the intermittent addition of $2 \mathrm{M}-\mathrm{KOH}$.

Measurement of rates of glucose utilization and succinoglucan production by cell suspensions. Suspensions of $A$. radiobacter ( $3 \mathrm{mg}$ dry wt cells in $3 \mathrm{ml} 20 \mathrm{mM}$-HEPES, pH 7.0) were incubated at $30^{\circ} \mathrm{C}$ in an open-topped oxygen electrode vessel (Rank). The suspension was mixed continuously using a magnetic stirrer so as to ensure that the dissolved oxygen concentration exceeded $50 \%$ saturation. Incubations were started by adding D-[U-14 Clglucose [0.5 mCi mmol $\left.\mathrm{m}^{-1}\left(18.5 \mathrm{MBq} \mathrm{mmol}^{-1}\right) ; 2.25 \mu \mathrm{Ci}(0.083 \mathrm{MBq})\right]$ to give a final concentration of $1.5 \mathrm{mM}$. Samples $(0.3 \mathrm{ml})$ of the cell suspension were removed at intervals over a period of $45 \mathrm{~min}$, the cells were pelleted using centrifugation $(13000 \mathrm{~g}$ for $1 \mathrm{~min})$ and a sample $(25 \mu \mathrm{l})$ of each supernatant was loaded onto Whatman DE 81 chromatography paper. The papers were developed using $20 \mathrm{mM}-\mathrm{HEPES}, \mathrm{pH} 7.0$ and then dried at $100^{\circ} \mathrm{C}$ for $15 \mathrm{~min}$ (glucose migrated with the solvent front and succinoglucan remained at the origin using this system). Regions of the chromatograms that contained glucose and succinoglucan were located precisely using autoradiography, then cut out, immersed in $3 \mathrm{ml}$ Optiscint T (LKB) and counted using a Hewlett Packard TriCarb liquid scintillation counter $(50-60 \%$ efficiency).

Estimation of flux control coefficients for glucose transport on respiration and succinoglucan production. These were measured using a variation of the inhibitor titration method initially described by Groen et al. (1982) and subsequently modified by Kell \& Westerhoff $(1986 a, b)$. The rates of glucose uptake and respiration by suspensions of $A$. radiobacter strain AR18 were measured as described previously (Cornish et al., 1987, 1989). Assays were started by adding D-glucose to give a final concentration of $250 \mu \mathrm{M}$ and the rate of glucose uptake was varied using appropriate concentrations (0-1.5 mM) of a competitive inhibitor of the glucose transport system, 6-chloro-6-deoxy-D-glucose. Rates of glucose uptake and respiration were measured respectively over the first $1 \mathrm{~min}$ and 2 min after adding glucose. Rates of glucose utilization and succinoglucan production by cell suspensions were measured as described above except that incubations were started by adding $\mathrm{D}-\left[\mathrm{U}-{ }^{-14} \mathrm{C}\right] \mathrm{glucose}\left[0.5 \mathrm{mCi} \mathrm{mmol}^{-1}\right.$ $\left.\left(18.5 \mathrm{MBq} \mathrm{mmol}^{-1}\right) ; 2.25 \mu \mathrm{Ci}(0.083 \mathrm{MBq})\right]$ to give a final concentration of $1 \mathrm{~mm}$ and measurements were carried 
out over a period of $12 \mathrm{~min}$ in the presence and absence of 6-chloro-6-deoxy-D-glucose (0-2 mM); no more than $30 \%$ of the added glucose was consumed during the assays, even in the absence of inhibitor. As the $K_{\mathrm{m}}$ for glucose transport is $<1 \mu \mathrm{M}$ (Cornish $e t$ al., 1988) the transport system was initially completely saturated in all experiments. Flux control coefficients were determined by plotting the normalized rates of glucose uptake, respiration and succinoglucan production versus the inhibitor concentration as described by Walter et al. (1987).

Assay of enzyme activities in cell-free extracts. Cell-free extracts were prepared as described previously (Cornish et al., 1987). The following enzymes were assayed at $30^{\circ} \mathrm{C}$ using modifications of established procedures (given in parentheses): hexokinase, phosphoglucomutase, phosphofructokinase and UDP-glucose pyrophosphorylase (Bergmeyer, 1974); glucose-6-phosphate dehydrogenase and 6-phosphogluconate dehydrogenase (NADP+linked) (Beardsmore et al., 1982); 6-phosphogluconate dehydratase plus 2-keto-3-deoxy-6-phosphogluconate aldolase (Wood, 1971); and UDP-galactose-4-epimerase (Maxwell et al., 1962).

Other methods. Purification of periplasmic glucose-binding proteins, SDS-PAGE and measurement of substrate binding using equilibrium dialysis were done as described previously (Comish et al., 1988).

Presentation of data. Where appropriate, values have been given as the mean \pm SBM with the number of determinations in parentheses.

Chemicals. D- $\left[\mathrm{U}^{-14} \mathrm{C}\right.$ Glucose $\left[270 \mathrm{mCi} \mathrm{mmol}^{-1}\left(10 \mathrm{GBq} \mathrm{mmol}^{-1}\right)\right]$ was purchased from Amersham. 6-Chloro-6deoxy-D-glucose was obtained from Sigma. Other reagents were purchased from Fisons and were of the highest grade available.

\section{RESULTS}

Glucose transport during growth of $A$. radiobacter in contimuous culture under ammonia limitation

Having established that $A$. radiobacter takes up glucose using two periplasmic, glucosebinding proteins [viz. GBP1 $\left(M_{\mathrm{r}}=36500\right)$ and GBP2 $\left(\boldsymbol{M}_{\mathrm{r}}=33500\right)$ ] during growth under glucose limitation (see accompanying paper: Comish et al., 1988) it was decided to investigate whether the same transport systems were active during ammonia-limited growth and to elucidate possible mechanisms by which glucose uptake might be regulated.

Cells which had been grown under ammonia limitation $\left(D=0.045 \mathrm{~h}^{-1}\right)$ transported glucose

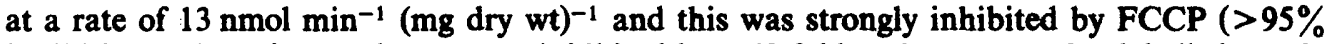
inhibition at $20 \mu \mathrm{M}$ ). Uptake was not inhibited by a 40 -fold molar excess of unlabelled $\alpha-1-O$ methyl-D-glucose or 3-O-methyl-D-glucose (and was only reduced by approximately $20 \%$ in the presence of 2-deoxy-D-glucose), but was reduced by $87 \%$ in response to an osmotic shock. SDSPAGE analysis indicated that more than twenty periplasmic proteins were released by this procedure, and two of these were identified as GBP1 and GBP2 on the basis of their elution characteristics on anion-exchange FPLC, their size on SDS-PAGE and their capacity to bind glucose as medsured by equilibrium dialysis. These results thus confirmed that the same glucosebinding proteins were involved in glucose transport during growth under glucose and ammonia limitation. It should be noted, however, that GBP1 and GBP2 amounted to only approximately $3 \%$ of the total cell protein during ammonia-limited growth compared with much higher levels during growth under glucose limitation (Cornish et al., 1988).

\section{Kinetics of glucose uptake and succinoglucan production during growth of $A$. radiobacter in con-} tinuous culture under different nutrient limitations at a dilution rate of $0.045 \mathrm{~h}^{-1}$

The derepression of the glucose uptake systems of $A$. radiobacter in response to the low substrate concentration during growth under glucose limitation was reflected in the rates of glucose uptake and utilization by washed cell suspensions, both of which were significantly greater than the in situ rate of $9 \mathrm{nmol} \mathrm{min}^{-1}$ ( $\mathrm{mg}$ dry wt) ${ }^{-1}$ (Linton et al., 1987a) (Table 1). Succinoglucan was not produced during glucose-limited growth, and all of the carbon taken up by the organism was converted into cell material plus $\mathrm{CO}_{2}$ under these conditions (Linton et al., 1987 a). Washed cells also failed to produce detectable amounts of succinoglucan when provided with excess glucose, thus suggesting that at least one of the enzymes involved in exopolysaccharide synthesis was strongly repressed (or uninduced) during glucose-limited growth.

The glucose transport rates measured for washed cells which had been grown under glucose excess conditions (i.e. under ammonia or $\mathbf{K}^{+}$limitation) were always lower than the rates of glucose utilization (Table 1), suggesting that a significant proportion of the glucose taken up was 
Table 1. Rates of glucose uptake, glucose utilization and succinoglucan production by $A$. radiobacter grown in continuous culture under different nutrient limitations $\left(D=0.045 h^{-1}\right)$

Rates of glucose uptake and utilization by washed cell suspensions were measured as described in Methods. Two ammonia-limited steady states were investigated; in both cases the cell density was maintained at $1.1 \mathrm{~g} \mathrm{dry} \mathrm{wt} 1^{-1}$ by fixing the input concentration of ammonium sulphate at $0.5 \mathrm{~g} \mathrm{I}^{-1}$, but glucose was supplied to the culture at an input concentration of either $16 \mathrm{~g} \mathrm{l}^{-1}(a)$ or $4 \mathrm{~g} \mathrm{I}^{-1}(b)$ such that in the latter case the rate of succinoglucan production was determined by the availability of glucose.

\begin{tabular}{|c|c|c|c|}
\hline $\begin{array}{l}\text { Limiting } \\
\text { nutrient }\end{array}$ & $\begin{array}{l}\text { Rate of } \\
\text { glucose } \\
\text { uptake } \\
\text { [nmol } \text { min }^{-1}\end{array}$ & $\begin{array}{l}\text { Rate of } \\
\text { glucose } \\
\text { utilization } \\
\left.\text { dry } w)^{-1}\right]\end{array}$ & $\begin{array}{c}\text { In situ rate of } \\
\text { succinoglucan } \\
\text { production } \\
{\left[\mathrm{g} \mathrm{h}^{-1}(\mathrm{~g} \text { dry } \mathbf{w t})^{-1}\right]}\end{array}$ \\
\hline $\begin{array}{l}\text { Glucose } \\
\text { Ammonia }^{a} \\
\text { Ammonia }^{b} \\
\mathrm{~K}^{+}\end{array}$ & $\begin{array}{l}55 \pm 3 \\
10 \pm 0.5(3) \\
24 \pm 1 \\
17\end{array}$ & $\begin{array}{l}45 \pm 1(7) \\
19 \pm(1) \\
30 \pm 2(4) \\
32 \pm 1(3)\end{array}$ & $\begin{array}{c}0 \\
0.21 \pm 0.01(3) \\
0.04 \pm 0.00(3) \\
0.08 \pm 0.00(3)\end{array}$ \\
\hline
\end{tabular}

subsequently lost as a result of further metabolism (e.g. as succinoglucan and $\mathrm{CO}_{2}$ ). Nevertheless, the results clearly indicated that the capacity of the organism to transport glucose was only partially repressed during growth under carbon-excess conditions, such that the quantity of glucose taken up greatly exceeded that required for growth (assuming that this was the same as during glucose limitation at the same dilution rate).

The highest rates of succinoglucan production $\left[0.21 \mathrm{~g} \mathrm{~h}^{-1}(\mathrm{~g} \text { dry wt})^{-1}\right]$ were obtained during ammonia-limited growth when all of the surplus glucose taken up is used to produce exopolysaccharide (Linton et al., 1987a, b). However, by decreasing the input concentration of glucose it was possible to grow the organism under ammonia-limitation such that the rate of succinoglucan production was determined by the availability of glucose (i.e. the cells were ammonia-limited for growth, but glucose-limited for succinoglucan production). Washed cells prepared from cultures which had been grown under these conditions utilized glucose at approximately twice the in situ rate $\left[30 \mathrm{nmol} \mathrm{min}{ }^{-1}\left(\mathrm{mg} \mathrm{dry} \mathrm{wt}^{-1}\right.\right.$ ef. $14 \mathrm{nmol} \mathrm{min}-1$ (mg dry wt $)^{-1}$ ] yet produced succinoglucan at a rate of only $0.03 \mathrm{~g} \mathrm{~h}^{-1}(\mathrm{~g} \mathrm{dry} \mathrm{wt})^{-1}$, which was similar to the in situ value of $0.04 \mathrm{~g} \mathrm{~h}^{-1}(\mathrm{~g} \text { dry wt) })^{-1}$. This observation suggested that the enzymes responsible for succinoglucan synthesis were not induced maximally in response to ammonialimited growth per se, but that their activities were regulated precisely such as to ensure that any surplus glucose taken up was incorporated into exopolysaccharide. During $\mathrm{K}^{+}$-limited growth the organism took up glucose at a rate of $32 \mathrm{nmol} \mathrm{min}^{-1}$ (mg dry wt) ${ }^{-1}$ but produced succinoglucan at a rate of only $0.08 \mathrm{~g} \mathrm{~h}^{-1}\left(\mathrm{~g} \mathrm{dry} \mathrm{wt}^{-1}\right.$ (Table 1$)$. This is explained by the observation that $\boldsymbol{A}$. radiobacter respires very rapidly during $\mathrm{K}^{+}$-limited growth, presumably to conserve energy in order to reconcentrate $\mathrm{K}^{+}$against a large concentration gradient (Hueting et $a l ., 1979$ ), and consequently most of the glucose taken up is oxidized to $\mathrm{CO}_{2}$ rather than being incorporated into succinoglucan (Linton et al., 1987b).

\section{Activities of enzymes involved in the early stages of glucose catabolism and succinoglucan biosynthesis}

The activities of various enzymes putatively involved in the early stages of glucose catabolism and succinoglucan biosynthesis were measured in cell-free extracts following growth under glucose and ammonia limitation $\left(D=0.045 \mathrm{~h}^{-1}\right)$. The observed complement of catabolic enzymes (Table 2) showed that the organism was capable of metabolizing glucose using both the Entner-Doudoroff and hexose monophosphate pathways; the absence of phosphofructokinase activity indicated that glucose was not being degraded via the Embden-Meyerhoff pathway. Hexokinase, glucose-6-phosphate dehydrogenase and the Entner-Doudoroff enzymes were repressed to a significant extent during growth under ammonia limitation.

It has previously been shown that most bacterial exopolysaccharides are synthesized from nucleotide diphosphate sugars and their derivatives (Sutherland, 1982) and for the purpose of 
Table 2. Activities of enzymes involved in the catabolism of glucose and in the production of succinoglucan precursors in cell-free extracts of $A$. radiobacter prepared from cells grown in continuous culture under glucose or ammonia limitation $\left(D=0.45 h^{-1}\right)$

Enzymes activities were measured in cell-free extracts as described in Methods. The Entner-Doudoroff enzymes (6-phosphogluconate dehydratase plus 2-keto-3-deoxy-6-phosphogluconate aldolase) were measured in combination.

Enzyme activities

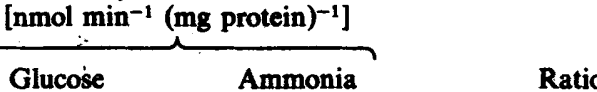

Enzyme

limitation

limitation

(ammonia/glucose)

Hexokinase

Glucose-6-phosphate dehydrogenase

6-Phosphogluconate dehydrogenase

$100 \pm 5(4)$

$93 \pm 10(4)$

$114 \pm 5(4)$

Entner-Doudoroff enzymes

Phosphoglucomutase

$67 \pm 8(3)$

$625 \pm 35(3)$

UDP-glucose pyrophosphorylase

UDP-galactose-4-epimerase

$184 \pm 12(3)$

$18 \pm 3(3)$

$75 \pm 3(5)$

$45 \pm 3(4)$

$109 \pm 9(4)$

$49 \pm 8(4)$

$557 \pm 72(4)$

$158 \pm 7(4)$

13

(2)

0.75

0.48

0.96

0.73

0.89

0.86

0.72

the present work it has been assumed that UDP-glucose and UDP-galactose (and their acetylated, pyruvylated and succinylated derivatives) are the precursors of succinoglucan. All of the enzymes needed to convert glucose 6-phosphate to UDP-glucose and UDP-galactose were present during growth under both glucose and ammonia limitation (Table 2), i.e. none of the enzymes involved in precursor synthesis were induced during ammonia-limited growth when succinoglucan was produced at high rates (indeed, the activity of UDP-galactose-4-epimerase was slightly lower under these conditions).

All of the enzyme activities were sufficient to account for the carbon flux to cell material and, in the case of ammonia-limited growth, to succinoglucan.

\section{Succinoglucan production by strains of $A$. radiobacter which differentially express $G B P 1$ and GBP2}

The above results indicate that the glucose uptake system of $A$. radiobacter was only partially repressed during growth under glucose excess conditions, such that considerably more glucose was taken up than was needed for growth purposes. It seemed possible, therefore, that the activities of the glucose transport systems might play an important role in determining the rate at which glucose was converted into succinoglucan during ammonia-limited growth. $A$. radiobacter has previously been shown to adapt to prolonged growth under glucose limitation by segregating into different strains in which either GBP1 (strain AR18) or GBP2 (strain AR9), but not both, were hyperproduced compared with the parent organism (Cornish et al., 1988). The possibility was therefore considered that the glucose uptake systems of these strains might also be less susceptible to repression during ammonia-limited growth, such that glucose would be taken up faster and hence converted into succinoglucan at higher rates. The capacity of $A$. radiobacter strains AR9 and AR18 to produce succinoglucan during growth under ammonia limitation $\left(D=0.045 \mathrm{~h}^{-1}\right)$ was therefore investigated.

$A$. radiobacter strain AR9 produced succinoglucan at the same rate as the parent organism during ammonia-limited growth, and the glucose uptake systems of the two strains were both substantially repressed (Table 3). By contrast, the glucose uptake system of strain AR18 was repressed much less strongly and this strain produced succinoglucan at a significantly higher rate than either the parent organism or strain AR9. These observations suggested that the glucose transport system involving GBP1 was indeed less sensitive to repression than that involving GBP2, and provided further evidence that the activity of the glucose uptake system was an important factor in determining the rate of succinoglucan production. Unlabelled D-galactose, which competes effectively with glucose for GBP1 but not GBP2 in vitro 
Table 3. Rates of glucose uptake and succinoglucan production by various strains of $A$. radiobacter grown in continuous culture under ammonia-limitation $\left(D=0.045 \mathrm{~h}^{-1}\right)$

The rates of glucose uptake by washed suspensions and of succinoglucan production by growing cultures were measured as described in Methods. The results shown for strains AR9 and AR18 refer to separate experiments.

\begin{tabular}{|c|c|c|c|}
\hline \multirow[b]{2}{*}{ Strain } & \multirow[b]{2}{*}{$\begin{array}{c}\text { Glucose uptake rate } \\
\left.\text { [nmol } \min ^{-1}(\mathrm{mg} \text { dry } w)^{-1}\right]\end{array}$} & \multicolumn{2}{|c|}{$\begin{array}{c}\text { In situ rate of succinoglucan } \\
\text { production }\end{array}$} \\
\hline & & $\overbrace{\left[g h^{-1}(g \text { dry wt })^{-1}\right]}$ & $(\%)$ \\
\hline $\begin{array}{l}\text { Parent } \\
\text { AR9 } \\
\text { AR9 } \\
\text { AR18 } \\
\text { AR18 } \\
\text { AR18 }\end{array}$ & $\begin{array}{l}10 \pm 1(3) \\
14 \pm 1(4) \\
12 \quad(2) \\
19 \pm 1(3) \\
21 \pm 1(3) \\
19 \quad(1)\end{array}$ & $\begin{array}{l}0.21 \pm 0.01(3) \\
0.20 \pm 0.01(5) \\
0.21 \pm 0.02(4) \\
0.29 \pm 0.01(4) \\
0.31 \pm 0.02(4) \\
0.29 \pm 0.02(3)\end{array}$ & $\begin{array}{r}100 \\
97 \\
102 \\
141 \\
150 \\
141\end{array}$ \\
\hline
\end{tabular}

Table 4. Production of succinoglucan by various strains of A. radiobacter during batch culture with glucose or sucrose as carbon source

The various strains were inoculated into a medium containing a low concentration of ammonium sulphate $\left(0.22 \mathrm{~g}^{-1}\right)$ and thereafter grew exponentially until they became starved of ammonia (final cell density $=0.5 \mathrm{~g}$ dry $\mathrm{wt}^{-1}$ ) and produced succinoglucan. The cultures were harvested $24 \mathrm{~h}$ after inoculation and the rates of succinoglucan production were determined as described in Methods.

$\begin{array}{llcr} & & \begin{array}{c}\text { In situ rate of succinoglucan } \\ \text { production following } \\ \text { ammonia exhaustion }\end{array} \\ \text { Strain } & \begin{array}{c}\text { Carbon } \\ \text { source }\end{array} & \overbrace{\text { [g h}}^{-1}(\mathrm{~g} \text { dry wt) })^{-1}] & (\%) \\ \text { Parent } & \text { Glucose } & 0.20 \pm 0.01(3) & 100 \\ & \text { Sucrose } & 0.19 \pm 0.01(3) & 95 \\ \text { AR9 } & \text { Glucose } & 0.20 \pm 0.01(3) & 100 \\ & \text { Sucrose } & 0.16 \pm 0.01(3) & 80 \\ \text { AR18 } & \text { Glucose } & 0.29 \pm 0.02(4) & 145 \\ & \text { Sucrose } & 0.19 \pm 0.01(4) & 95\end{array}$

(Cornish et al., 1988), reduced the rates of glucose uptake by strains AR9 and AR18 by approximately $50 \%$ and $95 \%$ respectively when it was added to cell suspensions at a 40 -fold molar excess over $\left[{ }^{14} \mathrm{C}\right]$ glucose, confirming that strain AR18 takes up glucose using predominantly GBP1 during ammonia-limited growth whereas strain AR9 apparently uses GBP1 and GBP2 to a similar extent.

$A$. radiobacter strain AR18 also produced succinoglucan at significantly higher rates than either strain AR9 or the parent organism during batch culture experiments in which glucose was used as the carbon source (Table 4), but the three strains produced succinoglucan at similar rates when glucose was replaced by sucrose. These results therefore further supported the view that an enzyme involved specifically with glucose uptake or metabolism had become de-repressed in strain AR 18 relative to the other strains, thereby enabling it to convert glucose into succinoglucan at a higher rate.

Relationship between the rate of succinoglucan production and the activity of the glucose uptake system of $A$. radiobacter grown under ammonia limitation $\left(D=0.045 h^{-1}\right)$

It had been noted previously that $A$. radiobacter produced succinoglucan at progressively lower rates during prolonged growth under ammonia limitation $\left(D=0.045 \mathrm{~h}^{-1}\right)(\mathrm{J}$. W. Drozd, unpublished observations) and the same phenomenon was observed in the present work with strain AR9. The rate at which this strain produced succinoglucan decreased slowly from 0.20 to 


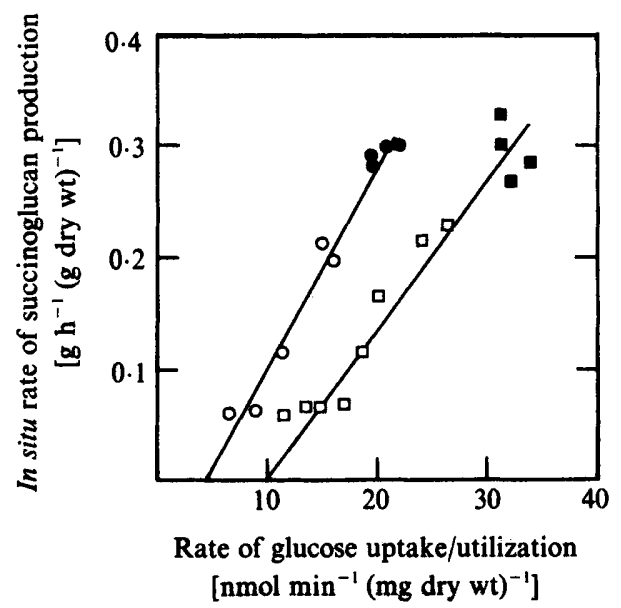

Fig. 1. Relationship between the rates of glucose uptake and utilization by washed cells and the rate of succinoglucan production in situ by $A$. radiobacter strains AR9 and AR18 grown in continuous culture under ammonia limitation $\left(D=0.045 \mathrm{~h}^{-1}\right)$. Strain AR9 was grown for 50 generations, during which time the rate of succinoglucan production decreased substantially (see text). Measurements were made on strain AR18 within 15 generation times of the steady state being established. Rates of glucose uptake $(O, O)$ and utilization $(\square, \square)$ by washed cell suspensions of strain AR9 (open symbols) and strain AR18 (closed symbols) are shown.

$0.16 \mathrm{~g} \mathrm{~h}^{-1}\left(\mathrm{~g} \mathrm{dry} \mathrm{wt}^{-1}\right.$ during the first 30 generations of ammonia-limited growth, then more rapidly to a value of $0.07 \mathrm{~g} \mathrm{~h}^{-1}$ ( $\mathrm{g}$ dry wt) $)^{-1}$ over the next 16 generations, but thereafter remained constant. This decay in the rate of succinoglucan production was not due to the emergence of mutants that had completely lost the capacity to produce exopolysaccharide (e.g. as a result of a lesion in the biosynthetic pathway) since only mucoid colonies were observed when samples were removed from the decayed culture and plated on to a solid medium that supported succinoglucan production. Neither was it due to the repression of enzymes involved in the early stages of glucose metabolism or in the production of succinoglucan precursors since the activities of the enzymes listed in Table 2 remained constant throughout the entire period of ammonia-limited growth. There was, however, a strong correlation throughout the decay process between the rates at which strain AR9 produced succinoglucan and transported glucose, and this relationship also held true when succinoglucan was being produced by strain AR18 at the much higher rate of $0.3 \mathrm{~g} \mathrm{~h}^{-1}(\mathrm{~g} \mathrm{dry} \mathrm{wt})^{-1}$ (Fig. 1); the subsequent decay in the rate of succinoglucan production by strain AR18 has not been investigated. The data therefore indicated that the rate at which the organism produced succinoglucan was determined primarily by the activity of the glucose uptake system. It remains to be established, however, why the rate of succinoglucan production diminished during prolonged growth under ammonia-limitation, but a plausible explanation might be that the glucose uptake system became progressively repressed (e.g. by a reversal of the process that leads to their de-repression during glucoselimited growth; see Cornish et al., 1988).

It was notable that the plots in Fig. 1 did not pass through the origin but intercepted the abscissa. The intercept value for the rate of glucose utilization was similar to the rate at which A. radiobacter consumed glucose in situ $\left[9 \mathrm{nmol} \mathrm{min}^{-1}(\mathrm{mg} \text { dry wt) })^{-1}\right]$ during glucose-limited growth. The intercept value for the rate of glucose uptake was lower than this, but it should be remembered that the measured rates of glucose uptake were lower than the actual rates of glucose utilization because a significant proportion (up to $40 \%$ ) of the label taken up by the cells was lost due to further metabolism. These observations clearly support the proposal that $A$. radiobacter produced succinoglucan during ammonia-limited growth in order to dispose of any transported glucose that was surplus to the requirement for growth. 


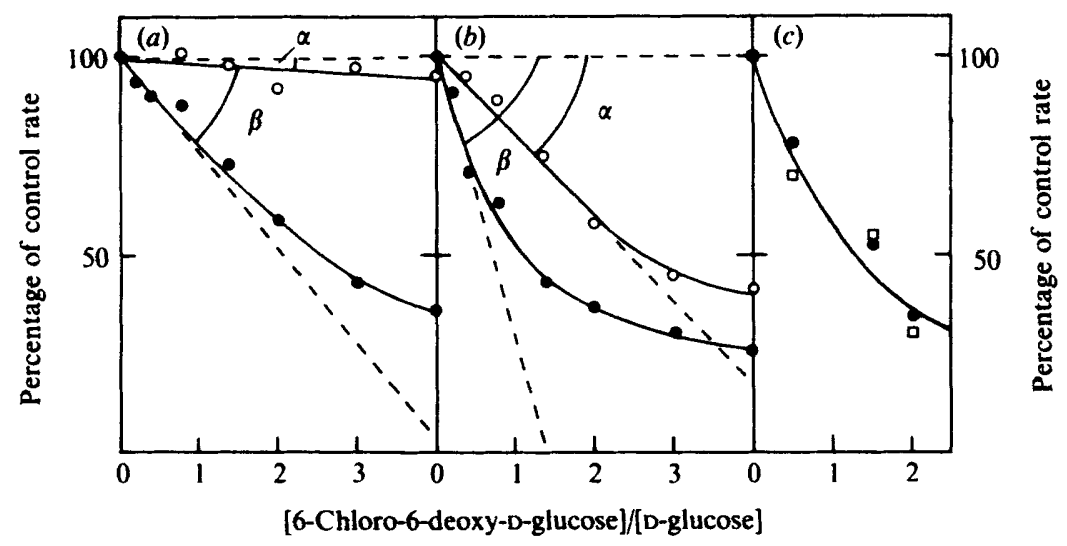

Fig. 2. Effect of 6-chloro-6-deoxy-D-glucose on glucose uptake, respiration and succinoglucan production by washed cells of $A$. radiobacter strain $A R 18$ grown in continuous culture under glucose or ammonia limitation $\left(D=0.045 \mathrm{~h}^{-1}\right)$. Rates of glucose uptake $(O)$, respiration $(O)$ and succinoglucan production $(\square)$ by washed cell suspensions prepared from $(a)$ glucose-limited cultures and $(b, c)$ ammonia-limited cultures were measured as described in Methods. 6-Chloro-6-deoxy-D-glucose was added to cell suspensions $5 \mathrm{~s}$ before D-glucose. Flux control coefficients for glucose transport on respiration and succinoglucan production are given by the ratios of the $\operatorname{tangents~(i.e.~} \tan \alpha / \tan \beta$ ) to the initial slopes of the plots (Kell \& Westerhoff, 1986a, b; Walter et al., 1987). The uninhibited rates of glucose uptake, respiration and succinoglucan production were as follows: $74 \mathrm{nmol} \mathrm{min}{ }^{-1}$ (mg dry

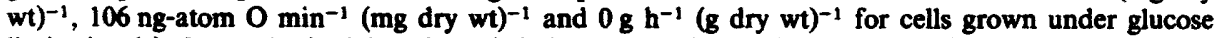
limitation (a); $20 \mathrm{nmol} \mathrm{min}{ }^{-1}$ ( $\mathrm{mg}$ dry wt) ${ }^{-1}, 85 \mathrm{ng}$ atom $\mathrm{O} \mathrm{min}^{-1}$ ( $\mathrm{mg} \mathrm{dry} \mathrm{wt)-1} \mathrm{and} 0.19 \mathrm{~g} \mathrm{~h}^{-1}$ (g dry $w t)^{-1}$ for cells grown under ammonia limitation $(b, c)$. Note that the rate of succinoglucan production by washed cells is approximately $30 \%$ lower that the in situ rate.

\section{Effect of 6-chloro-6-deoxy-D-glucose on respiration and succinoglucan production by A. radiobacter strain $A R 18$}

It had previously been established that the glucose transport system of $A$. radiobacter strain AR18 was inhibited by 6-chloro-6-deoxy-D-glucose, which also competed effectively with D-glucose for GBP1 in vitro (Cornish et al., 1988). It was therefore considered possible to determine the extent to which the rates of respiration and succinoglucan synthesis were controlled by the activity of the glucose transport system by measuring in parallel the effect of 6chloro-6-deoxy-D-glucose on these reactions.

Concentrations of 6-chloro-6-deoxy-D-glucose which were sufficient to bring about a substantial inhibition of glucose transport by whole cells of strain AR18 grown under glucose limitation had little effect on the rate of respiration (Fig. 2a). A value of 0.1 (range 0.09-0.11) was calculated for the flux control coefficient of glucose transport on respiration using the method of Walter et al. (1987) (see also Kell \& Westerhoff, 1986), thus indicating that the activity of the glucose transport system was only of minor importance in controlling respiration. It is important to note that the rate of glucose transport measured in this experiment was an underestimate of the true rate (see above), and it was therefore necessary to assume that the effect of the inhibitor on the apparent rate and the real rate was identical. The low flux control coefficient was commensurate with the earlier observation that the glucose uptake system of strain AR18 was substantially derepressed during glucose-limited growth (Cornish $e$ t al., 1988) such that in the presence of excess glucose the rate of glucose uptake was extremely high and greatly exceeded the rate of further metabolism.

By contrast, the rates of glucose uptake and respiration by cells which had been grown under ammonium limitation were both substantially inhibited by 6-chloro-6-deoxy-D-glucose (Fig. $2 b$ ), the flux control coefficient of 0.3 (range $0.21-0.44$ ) indicating that the lowered glucose transport capacity of these cells enabled the uptake system to contribute significantly to the control of respiration. Importantly, the rates of glucose uptake and succinoglucan production by these cells 


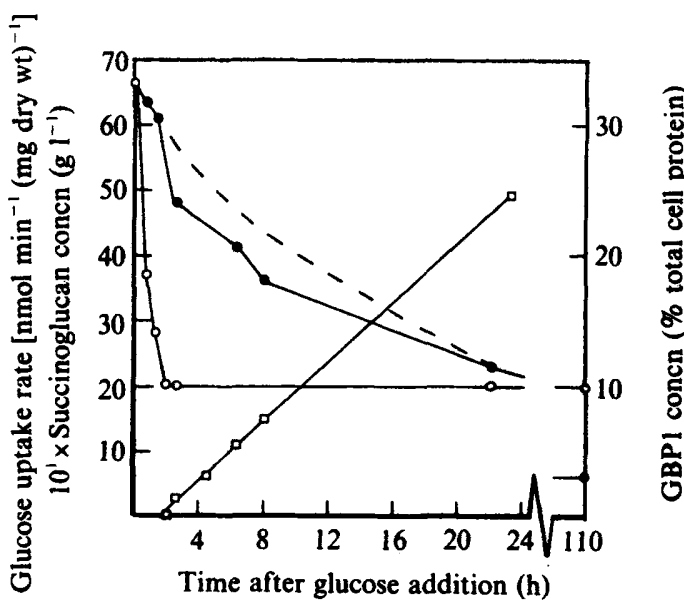

Fig. 3. Changes in the activity of the glucose uptake system of $A$. radiobacter strain AR 18 during the transition from glucose- to ammonia-limited growth. Strain AR18 was initially grown in continuous culture under glucose limitation at a dilution rate of $0.045^{-1}$ (input concentrations of glucose and ammonium sulphate were $1.9 \mathrm{~g} \mathrm{t}^{-1}$ and $0.5 \mathrm{~g} \mathrm{t}^{-1}$ respectively). At zero time, $5 \%$ of the culture was withdrawn and replaced with an equal volume of a glucose solution such that the final concentration of glucose in the chemostat was $16 \mathrm{~g} \mathrm{1}^{-1}$; the glucose concentration of the inflowing medium was also increased to $16 \mathrm{~g} \mathrm{l}^{-1}$ at the same time. Changes in the activity of the glucose uptake system $(0)$, the concentration of the major glucose-binding protein (i.e. GBP1) (O) and the concentration of succinoglucan $(\square)$ were monitored following addition of excess glucose. - Theoretical decrease in the concentration of GBP1 assuming that the protein is diluted out during the subsequent growth of the organism and is not degraded by proteolysis. The curve was computed from the equation $F=F_{0} e^{-D x}$, where $F_{0}$ is the initial concentration of GBPl and $F$ is the fraction remaining at time $t, D=0.045 \mathrm{~h}^{-1}$ and $t$ is the time elapsed following addition of excess glucose (h). The concentration of GBP1 at each time point was determined by separating cellular proteins using SDS-PAGE and quantifying the extent of staining by Kenacid blue using microdensitometry.

were inhibited almost identically by 6-chloro-6-deoxy-D-glucose (Fig. 2c) to yield a flux control coefficient $\geqslant 0.8$. It is concluded, therefore, that glucose transport is the major kinetic control point for exopolysaccharide production.

It must be pointed out that this method of determining flux control coefficients is valid only if the inhibitor displays a high degree of specificity for the target enzyme. The observation that an 8- to 18-fold molar excess of 6-chloro-6-deoxy-D-glucose over glucose and glucose 6-phosphate had no effect on the activities of hexokinase and glucose-6-phosphate dehydrogenase respectively in cell-free extracts of $A$. radiobacter supported the view that it was inhibiting glucose transport and not the early stages of glucose metabolism. Furthermore, if it had additionally inhibited these other enzymes as a result of being transported into the cell then it would have exerted a similar effect on the respiration of cells grown under glucose or ammonia limitation.

\section{Kinetics of inactivation of the glucose uptake system of $A$. radiobacter strain AR18 during the transition from glucose- to ammonia-limited growth}

By selecting appropriate input concentrations of glucose and ammonium sulphate it was possible to grow $A$. radiobacter under glucose limitation $\left(D=0.45 \mathrm{~h}^{-1}\right)$ such that growth quickly became ammonia-limited when excess glucose was added to the culture. When a glucose-limited culture of $A$. radiobacter strain AR 18 was perturbed in this fashion, the activity of the glucose uptake system decreased from $66 \mathrm{nmol} \mathrm{min}$ m $^{-1}\left(\mathrm{mg}\right.$ dry wt) ${ }^{-1}$ to $20 \mathrm{nmol} \mathrm{min}^{-1}$ (mg dry wt) ${ }^{-1}$ within $2.5 \mathrm{~h}$ of adding excess glucose $\left(t_{1 / 2} 1 \mathrm{~h}\right)$ by which time the organism had also started to produce succinoglucan (Fig. 3). The concentration of GBP1 also began to decrease immediately, but the rate was much too slow $\left(t_{1 / 2} 14 \mathrm{~h}\right)$ to account for the reduction in glucose transport activity. 
Closer examination of the kinetics of GBP1 disappearance indicated that it was not being actively degraded, but was simply becoming diluted out in the periplasm as a result of subsequent growth. These results suggested that the activity of the glucose transport system was initially being regulated at the level of the membrane components, although it is not possible to state with any certainty that this is also true during steady-state ammonia-limited growth. The kinetics of inactivation of glucose transport were essentially the same when this experiment was repeated using the parent organism and strain AR9, even though in both these cases GBP2 was initially the most abundant glucose-binding protein and the final glucose uptake rates were significantly lower [10-14 $\mathrm{cf} .20 \mathrm{nmol} \mathrm{min}{ }^{-1}\left(\mathrm{mg} \mathrm{dry} \mathrm{wt}^{-1}\right]$. The organism evidently has the ability to effect a rapid and extensive shut down of glucose uptake, presumably in order to avoid the potentially deleterious consequences which would result from the rapid accumulation of very high concentrations of glucose. It is noteworthy that the organism can also synthesize an intracellular polysaccharide (Linton et al., 1987a) which can represent up to $30 \%$ of the dryweight of ammonia-limited cultures and may serve as a short-term disposal system to protect the cell for the $2-3 \mathrm{~h}$ period during which glucose uptake is being shut down.

\section{DISCUSSION}

The results of the present work have established that $A$. radiobacter takes up glucose during growth under ammonia limitation using the same periplasmic, glucose-binding proteins (i.e. GBP1 and GBP2) that are involved in glucose transport during glucose-limited growth. Both systems are maximally de-repressed during glucose-limited growth so as to enable the organism to take up glucose at a rate sufficient to satisfy the imposed dilution rate when the standing concentration of the growth-limiting substrate is low (Cornish et al., 1988). Under these conditions all of the available glucose is converted into cell material plus carbon dioxide (Linton et al., 1987a).

The glucose uptake systems are only partially repressed during ammonia-limited growth, particularly the system involving GBP1, and the organism takes up glucose at a rate which exceeds that required for growth. The potentially deleterious consequences of imperfectly controlled substrate uptake are avoided by converting any surplus glucose taken up into succinoglucan at a rate which is determined by the combined activity of the two transport systems. It seems unlikely that bacteria in general produce exopolysaccharides primarily as a means of disposing of excess carbon substrate [various functions have been proposed for exopolysaccharides and a variety of alternative 'overflow' mechanisms are known to operate in bacteria (Neijssel \& Tempest, 1975)], but succinoglucan synthesis apparently fulfils such a role in $A$. radiobacter.

By growing $A$. radiobacter under prolonged glucose limitation, and thereby imposing a strong selection pressure on the glucose transport system, it proved possible to isolate strains (of which AR18 is representative) that produce exopolysaccharide at much higher rates than the parent strain [i.e. $0.30 \mathrm{~g} \mathrm{~h}^{-1}$ ( $\mathrm{g}$ dry wt) ${ }^{-1}$ compared to $0.20 \mathrm{~g} \mathrm{~h}^{-1}$ (g dry wt) ${ }^{-1}$ during ammonia-limited growth]. The only apparent difference between the high-producing strains and the parent organism is that the former take up glucose predominantly using GBP1 rather than GBP2. The transport system involving GBP1 is less susceptible to repression by glucose (or metabolites thereof) than that involving GBP2 with the result that high-producing strains both take up glucose, and hence produce succinoglucan, at higher rates than the parent organism during ammonia-limited growth. Furthermore, flux control analysis shows that glucose uptake is a major kinetic control point for succinoglucan production, which suggests that it ought to be possible to obtain even higher rates of succinoglucan production by using recombinant DNA methods to increase the rate of glucose transport. In order to accomplish this, however, it might be necessary to overexpress all the components of the glucose transport systems since it is possible that the activity of one or more of the membrane proteins, and not the concentration of the glucose-binding proteins, determines the rate of glucose uptake during ammonia-limited growth. Cloning of the transport systems may not be difficult provided that the genes encoding the essential components are arranged within a single operon as has found to be the case for analogous sugar transport systems in Escherichia coli (Ames, 1986). 
Most of the available evidence indicates that ATP is probably the energy donor for transport systems that involve periplasmic, substrate-binding proteins (Higgins et al., 1985, 1986; but see Ames, 1986). If it is assumed that $1 \mathrm{~mol}$ of ATP is hydrolysed per mol of glucose taken up by $A$. radiobacter, then it can be calculated that approximately $30 \%$ of the energy consumed during the conversion of glucose into succinoglucan is expended on glucose transport (Linton et al., 1987a). In principle therefore, the energy demand for succinoglucan synthesis could be substantially reduced by constructing strains of $A$. radiobacter which take up glucose using energetically more efficient mechanisms (i.e. phosphotransferase, proton symport or facilitated diffusion systems). However, physiological studies involving a range of bacteria have indicated that exopolysaccharide synthesis provides an effective means of disposing of excess carbon substrate and turning over ATP during ammonia-limited growth (Linton et al., 1986, 1987a,b). It is possible, therefore, that the use of an alternative transport system might disrupt the energetic balance of succinoglucan synthesis to such an extent that the rate of polysaccharide production would be diminished rather than enhanced.

The authors are indebted to John Linton and Jan Drozd for useful discussions, and to Shell Research for financial support.

\section{REFERENCES}

AMEs, G. F.-L. (1986). Bacterial periplasmic transport systems: structure, mechanism and evolution. Annual Review of Biochemistry 55, 397-425.

BeARDSMORe, A. J., APERGHIS, P. N. G. \& QUAYLe, J. R. (1982). Characterization of the assimilatory and dissimilatory pathways of carbon metabolism during growth of Methylophilus methylotrophus on methanol. Journal of General Microbiology 128, 14231439.

BERGMEYER, H. U. (editor) (1974). Methods of Enzymatic Analysis, 2nd edn, vol. 1. New York \& London: Academic Press.

CORNISH, A., Linton, J. D. \& JoNEs, C. W. (1987). The effect of growth conditions on the respiratory system of a succinoglucan-producing strain of Agrobacterium radiobacter. Journal of General Microbiology 133, 2971-2978.

Cornish, A., Greenwood, J. A. \& Jones, C. W. (1988). Binding-protein-dependent glucose transport by Agrobacterium radiobacter grown in glucoselimited continuous culture. Journal of General Microbiology 134, 3099-3110.

Darzins, A., Nixon, L. L., Vanags, R. I. \& Charrabarty, A. M. (1985a). Cloning of Escherichia coli and Pseudomonas aeruginosa phosphomannose (isomerase genes and their expression in alginate-negative mutants of Pseudomonas aeruginosa. Journal of Bacteriology 164, 249-267.

Darzins, A., Wang, S.-K., Vanags, R. I. \& ChakraBARTY, A. M. (1985b). Clustering of mutations affecting alginic acid biosynthesis in mucoid Pseudomonas aeruginosa. Journal of Bacteriology 164, 516524.

Groen, A. K., Wanders,. R. J. A., Westerhoff, H. V., VAN DER MEER, R. \& TAGER, J. M. (1982). Quantification of the contribution of various steps to the control of mitochondrial respiration. Journal of Biological Chemistry 257, 2754-2757.

Higons, C. F., Hang, P. D., Whalley, K. \& JAMIESON, D. J. (1985). Nucleotide binding by membrane components of bacterial periplasmic binding protein-dependent transport systems. EMBO Journal 4, 1033-1040.
Higgns, C. F., Hiles, I. D., SAlmond, G. P. C., Gill, D. R., Downe, J. A., Evans, I. J., Holland, I. B., GrAY, L., BuCKel, S. D., BELL, A. W. \& HBRMODson, M. A. (1986). A family of related ATP-binding subunits coupled to many distinct biological processes in bacteria. Nature, London 323, 448-450.

Hueting, S., De LANG, T. \& TEMPEST, D. W. (1979). Energy requirement for maintenance of the transmembrane potassium gradient in Klebsiella aerogenes NCTC 418: a continuous culture study. Archives of Microbiology 123, 183-188.

KELL, D. B. \& WESTERHOFF, H. V. (1986a). Towards a rational approach to the optimization of flux in microbial transformations. Trends in Biotechnology 4, 137-142.

KeLL, D. B. \& WeSTERHOFF, H. V. (1986b). Metabolic control theory: its role in microbiology and biotechnology. FEMS Microbiology Reviews 39, 305-320.

LINTON, J. D., Evans, M., JonEs, D. S. \& Gouldney, D. N. (1987a). Exocellular succinoglucan production by Agrobacterium radiobacter NCIB 11883. Journal of General Microbiology 133, 2961-2969.

ferent pathways of $\mathrm{C}_{1}$ assimilation. Journal of General Microbiology 132, 779-788.

Linton, J. D., Evans, M., Jones, D. A. \& Gouldney, D. N. (1987a). Exocellular succinoglucan production by Agrobacterium radiobacter NCIB 11883 . Journal of General Microbiology 133, 2961-2969.

LINTON, J. D., JONEs, D. S. \& WOODARD, S. (1987b). Factors that control the rate of exopolysaccharide production by Agrobacterium radiobacter NCIB 11883. Journal of General Microbiology 133, 2979-2987.

Neussel, O. M. \& TeMpest, D. W. (1975). The regulation of carbohydrate metabolism in Klebsiella aerogenes NCTC 418 organisms growing in chemostat culture. Archives of Microbiology 106, 251-258.

MaXWell, E. S., KuRAHAshi, K. \& KalCar, H. M. (1962). Enzymes of the Leloir pathway. Methods in Enzymology 5, 174-190.

SuTHERLAND, I. W. (1982). Biosynthesis of microbial exopolysaccharides. Advances in Microbial Physio$\log y$ 23, 79-150. 
Thorne, L., TAnsey, L. \& Pollock, T. J. (1987). Clustering of mutations blocking synthesis of xanthan gum by Xanthomonas campestris. Journal of Bacteriology 169, 3593-3600.

WAlter, R. P., Morris, J. G. \& Kell, D. B. (1987). The roles of osmotic stress and water activity in the inhibition of growth, glycolysis and glucose phosphotransferase system of Clostridium pasteurianum. Journal of General Microbiology 133, 259-266.

Wood, W. A. (1971). Assay of enzymes representative of metabolic pathways. Methods in Microbiology 6A, 411-424. 